\title{
VIEWPOINT Saving global land resources by enhancing eco-efficiency of agroecosystems
}

Rattan Lal

E xpansion of land area under agroecosystems has numerous ecological and environmental consequences. Important among these are decline in habitat of natural species and reduction in biodiversity, increase in risks of accelerated erosion and nonpoint source pollution, and emission of greenhouse gases (GHGs; carbon dioxide $\left[\mathrm{CO}_{2}\right]$, methane $\left[\mathrm{CH}_{4}\right]$, and nitrous oxide $\left[\mathrm{N}_{2} \mathrm{O}\right]$ ) from the terrestrial biosphere into the atmosphere with the attendant increase in the risks of global warming. Thus, a great challenge facing humanity lies in advancing the Sustainable Development Goals of the United Nations (United Nations 2014) while restoring quality of natural resources (soil, water, and air) and saving land for nature conservancy. Therefore, the objective of this article is to discuss the conceptual basis of land-saving technologies for advancing food and nutritional security while improving the environment, adapting to and mitigating anthropogenic climate change, and enhancing biodiversity. This paper specifically focuses on one important dimension of the food security debate, and that is on the need to reduce (rather than expand) the use of land area, water, fertilizers, and pesticides, while achieving food and nutritional security and restoring the environment. The discussion provides hypothetical scenarios for increasing agricultural production while reducing the land area under agriculture along with reduction in the amount of water consumed for irrigation and a decline in the use of fertilizers.

\section{GLOBAL LAND AREA FOR AGRICULTURE}

Of the earth's total land area of $1.49 \times$ $10^{10}$ ha $\left(3.68 \times 10^{10} \mathrm{ac}\right), 1.04 \times 10^{10} \mathrm{ha}$ $\left(2.57 \times 10^{10} \mathrm{ac}\right)$ is the habitable land. Of the habitable land, $5.1 \times 10^{9}$ ha $(1.26 \times$ $\left.10^{10} \mathrm{ac}\right)$ is under agriculture $\left(1.17 \times 10^{9}\right.$

Rattan Lal is a distinguished professor of soil science and the director of the Carbon Management and Sequestration Center at The Ohio State University, Columbus, Ohio.

\section{Table 1}

Estimates of present (2000) and future (2030) land use (adapted from Lambin and Meyfroidt [2011], Gibbs and Salmon [2015], Bai et al. [2008]).

\begin{tabular}{lll}
\hline & Land area (ha $\left.\times \mathbf{1 0}^{\mathbf{6}}\right)$ \\
\cline { 2 - 3 } Land use & In $\mathbf{2 0 0 0}$ & Additional land area by 2030 \\
\hline Cropland & 1,510 to 1,611 & 81 to 147 \\
Biofuel crops & - & 44 to 118 \\
Grazing land/ pastures & 2,500 to 3,410 & 0 to 151 \\
Natural forests & 3,143 to 3,871 & - \\
Planted forests & 126 to 215 & 56 to 109 \\
Urban land & 66 to 351 & 48 to 100 \\
Unused productive land & 356 to 445 & - \\
Land lost to soil degradation & 500 to 1,000 & 30 to 87 \\
\hline
\end{tabular}

Note: Estimates of vegetation degradation may be on $24 \%$ of the earth's land area (Bai et al. 2008).

ha $\left[2.89 \times 10^{9} \mathrm{ac}\right]$ for crops and $3.93 \times$ $10^{9}$ ha $\left[9.71 \times 10^{9} \mathrm{ac}\right]$ for livestock), 3.9 $\times 10^{9}$ ha $\left(9.64 \times 10^{9} \mathrm{ac}\right)$ is under forests, $1.2 \times 10^{9}$ ha $\left(2.97 \times 10^{9} \mathrm{ac}\right)$ under shrubs and prairies, $1.5 \times 10^{8}$ ha $\left(3.7 \times 10^{8} \mathrm{ac}\right)$ under urban land, and $1.5 \times 10^{8}$ ha $(3.7 \times$ $10^{8} \mathrm{ac}$ ) under fresh water reservoirs (Roser and Ritchie 2017). The data on present and future land use shown in table 1 are based on the assumption that additional area would be needed for cropland, biofuel feedstocks, grazing land, and urbanization. In addition, as much as $3 \times 10^{7}$ to $8.7 \times$ $10^{7}$ ha $\left(7.4 \times 10^{7}\right.$ to $\left.2.1 \times 10^{8} \mathrm{ac}\right)$ would be lost to degradation processes such as erosion, salinization etc. (table 1). Estimates of additional resources needed by 2050 and beyond have been widely reported (Alexandrotos and Bruinsma 2012; Asubel et al. 2013; Bruinsma 2009; FAO 2009).

Conversion of natural land to agricultural ecosystems has been a prominent source of GHGs ever since the dawn of settled agriculture (Ruddiman 2003), and it has strongly affected the terrestrial carbon (C) balance. Gaseous emissions due to anthropogenic land cover change were large during the pre-industrial era (Reick et al. 2010). Estimates of the historic depletion of soil organic C (SOC) stock range from $135 \mathrm{Pg} \mathrm{C}\left(1.49 \times 10^{11}\right.$ tn C) ( $\mathrm{Lal} 2018)$ to $133 \mathrm{Pg} \mathrm{C}\left(1.47 \times 10^{11}\right.$ tn C) (Sanderman et al. 2017). It is also argued that historic $\mathrm{CO}_{2}$ emissions from land use change may have been underestimated (Arneth et al. 2017), and that the early per capita land use change was larger than reported (Ruddiman and Ellis 2009). Land cover change has also caused a strong decline in terrestrial biodiversity (Newbold et al. 2015). Therefore, any additional conversion of land from natural to agricultural and other managed (urban) ecosystems requires a critical and an objective consideration.

\section{ANTHROPOGENIC IMPACTS ON SOIL AND OTHER NATURAL RESOURCES}

Intense anthropogenic activities, especially since the 1960s, have strongly impacted the biogeochemical and biogeophysical cycles of water, $\mathrm{C}$, nitrogen $(\mathrm{N})$, and other elements. As much as $38 \%$ of the earth's terrestrial surface is already used for agriculture, of which three-fourths is used for raising livestock. About $70 \%$ of the global fresh water withdrawal is used for irrigation, and $30 \%$ to $35 \%$ of GHG emissions are contributed by agriculture. Yet, 1 in 9 persons (795 million people) are food-insecure, and 2 to 3 in 7 are malnourished and prone to hidden hunger (FAO 2015). Thus, there is a strong need of a paradigm shift in business-as-usual of managing agroecosystems.

There have also been drastic changes in the global $\mathrm{N}$ cycle, especially since the Industrial Revolution circa 1750. The global N fixation of $203 \mathrm{Tg}\left(2.2 \times 10^{8} \mathrm{tn}\right)$ 
in the preindustrial era has increased to $418 \mathrm{Tg}\left(4.6 \times 10^{8} \mathrm{tn}\right)$, including $140 \mathrm{Tg}$ $\mathrm{N} \mathrm{y}^{-1}\left(1.5 \times 10^{8}\right.$ tn $\left.\mathrm{N} \mathrm{yr}^{-1}\right)$ by biological $\mathrm{N}$ fixation in marine ecosystems (Canfield et al. 2010), $5 \mathrm{Tg} \mathrm{N} \mathrm{y}^{-1}\left(5.5 \times 10^{6}\right.$ tn $\mathrm{N}$ $\mathrm{yr}^{-1}$ ) by lightning (Tie et al. 2002), and 58 $\operatorname{Tg~} \mathrm{N} \mathrm{y}^{-1}\left(6.4 \times 10^{7} \mathrm{tn} \mathrm{N} \mathrm{yr}^{-1}\right)$ in terrestrial ecosystems (Vitousek et al. 2013; Fowler et al. 2013; Herridge et al. 2008; Battye et al. 2017). In addition, the reactive $\mathrm{N}$ produced by the fertilizer industry is $125 \mathrm{Tg}$ $\mathrm{N} \mathrm{y}^{-1}\left(1.4 \times 10^{8}\right.$ tn $\left.\mathrm{N} \mathrm{yr}^{-1}\right)$. Of the $418 \mathrm{Tg}$ of reactive $\mathrm{N}, 215 \mathrm{Tg}\left(2.4 \times 10^{8} \mathrm{tn} ; 51.4 \%\right)$ of the anthropogenic origin (Lal 2017a) is a cause of environmental pollution, including eutrophication, acidification of water, and emission of $\mathrm{N}_{2} \mathrm{O}$ into the atmosphere. Indiscriminate use of nitrogenous fertilizers has been responsible for these environmental concerns. Addition of phosphorus (P) as a fertilizer is another source of pollution, especially of algal bloom. A total cereal grain production of $2.508 \times 10^{9} \mathrm{t}(2.765$ $\left.\times 10^{9} \mathrm{tn}\right)$ in 2014 (FAOSTAT 2017) is achieved because of fertilizer use. However, the amount of $\mathrm{N}$ and $\mathrm{P}$ fertilizers applied in $2014\left(1.133 \times 10^{8} \mathrm{t}\left[1.249 \times 10^{8} \mathrm{tn}\right]\right.$ of $\mathrm{N}$ and $2.05 \times 10^{7} \mathrm{t}\left[2.26 \times 10^{7} \mathrm{tn}\right]$ of $\mathrm{P}$ ) were about 2.5 times more than that harvested in the grains. A large proportion of excessive fertilizer used is leaked into the environment and leads to emission of $\mathrm{N}_{2} \mathrm{O}$ and eutrophication of water as indicated by the growing problems of algal bloom and the hypoxia of coastal waters.

\section{CLIMATE CHANGE EFFECT ON SOIL RESOURCES AND CROP YIELD}

Increase in temperature related to projected global warming could lead to a net loss of global soil C stocks during the twenty-first century with a strong positive feedback such as the so-called, "compostbomb instability in drying organic soils" (Luke and Cox 2011). It is estimated that global SOC stocks may decrease by $30 \pm$ 30 to $203 \pm 161 \mathrm{Pg} \mathrm{C}\left(3.31 \times 10^{10} \pm 3.31\right.$ $\times 10^{10}$ to $\left.2.24 \times 10^{11} \pm 1.78 \times 10^{11} \mathrm{tn}\right)$ for each $1^{\circ} \mathrm{C}\left(1.8^{\circ} \mathrm{F}\right)$ increase in temperature, and that the loss of SOC from the upper soil horizons by 2050 may be as much as $55 \pm 50 \operatorname{Pg}\left(6.06 \times 10^{10} \pm 5.51 \times 10^{10} \mathrm{tn}\right)$ (Crowther et al. 2016).

South America, a region where agricultural expansion is occurring and presumably can occur, has its own environmental issues. The adverse impacts of the half a century of the process of economic integration of the Amazon on soil, water, biodiversity, and other natural resources cannot be overemphasized. The Amazon region, similar to that of Sumatra and the Congo Basin, may have two tipping points: (1) temperature increase of $4^{\circ} \mathrm{C}\left(7.2^{\circ} \mathrm{F}\right)$ by the projected climate change, and (2) deforestation exceeding $40 \%$ of the forest cover (Nobre et al. 2016). Thus, there is a strong need for a new global agricultural paradigm.

\section{ENHANCING ECO-EFFICIENCY}

The basic strategy is to enhance the use efficiency of inherent (i.e., plant nutrients and water) resources and external inputs (i.e., fertilizer, water, energy, and pesticides) by reducing losses (i.e., erosion, leaching, and volatilization). The goal is to increase agronomic productivity per unit of land area and per unit input of nutri- ents, pesticides, agrochemicals, energy, and emission of GHG. It is critical to adopt site/soil-specific best management practices (BMPs), narrow the yield gap (the difference between the attainable yield and the national average yield), and sustain productivity growth. Implementation of this strategy involves (1) replacing what is removed or depleted, (2) responding wisely to what is changed, (3) predicting what may happen to soil and water resources in the future, and (4) enhancing resilience of soils and agroecosystems (figure 1). Rather than expanding the land area under agricultural production, conversion of traditional to improved systems can save land for nature conservancy and restoration. The objective is to produce more from less and save resources for nature restoration and conservation.

There are several land saving options. For example, Phalan et al. (2016) proposed the following four linking mechanisms:

\section{Figure 1}

Basic principles of enhancing ecoefficiency of agroecosystems.

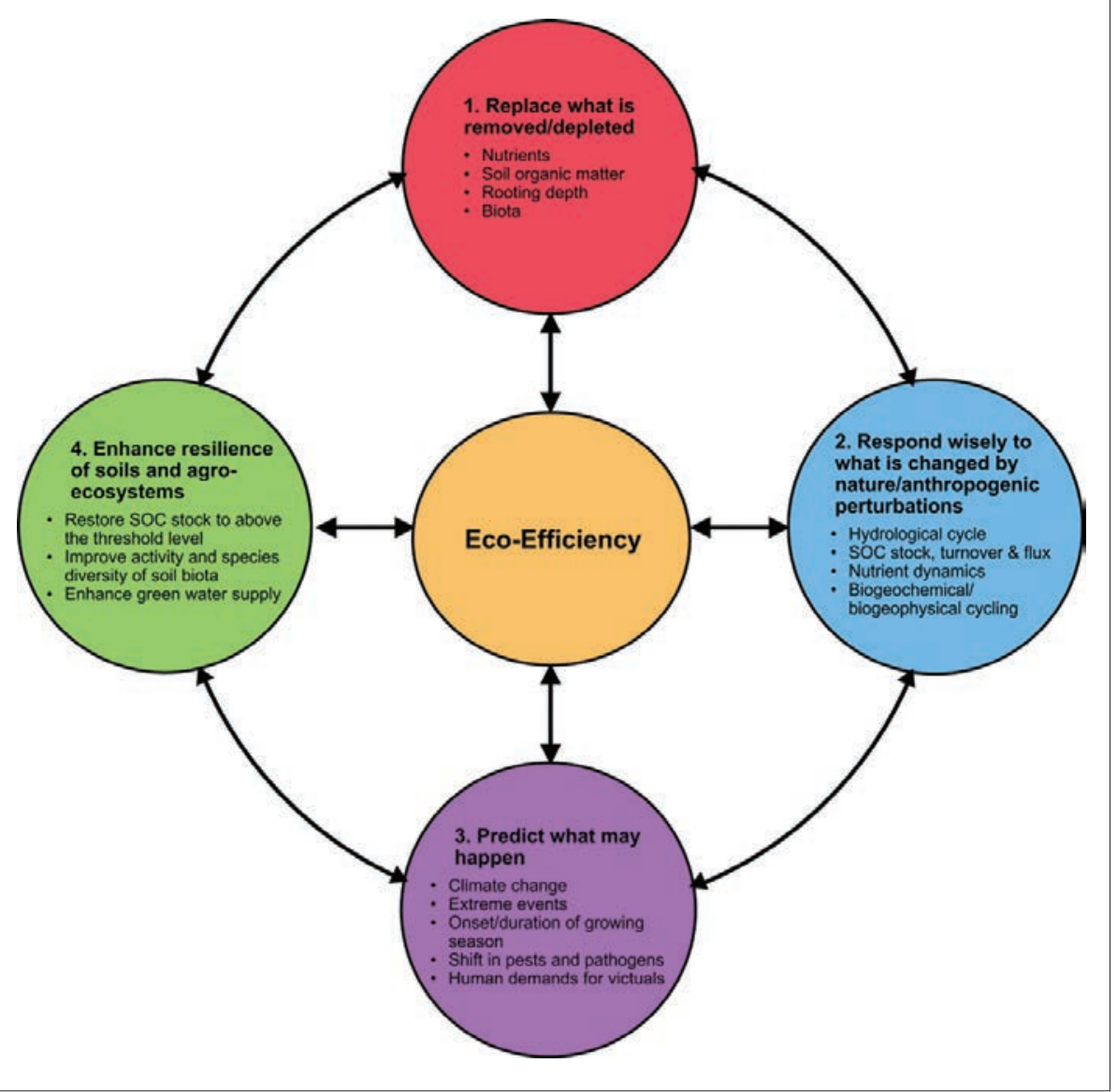


1. Land use zoning or "using the best and saving the rest" following the Boserpian innovation concept (an increase in population would stimulate technologies to increase food production, and the necessity is the mother of invention). Some ecologically sensitive ecoregions can be protected (off-limits), such as the tropical rainforest or highly erodible lands.

2. Incentivizing the adoption of BMPs through payments for ecosystem services, such as the Conservation Reserve Program in the United States,

3. Promoting knowledge-based soiland site-specific BMPs for enhancing yield (e.g., conservation agriculture, cover cropping, improved varieties and species, and drip subirrigation). Supplemented irrigation can lead to multiple cropping.

4. Adopting labor and capital-intensive technologies. This strategy is rooted in balancing economic and ecological goods by recognizing the ecological value of ecosystems (Frank and Schlenker 2016).

In this regard, agricultural innovation is essential to restoring and protecting the environment for a world of 11.2 billion people.

\section{ENAHCING SOIL ORGANIC CARBON AND RESTORING SOIL HEALTH}

Enhancing SOC concentration and stock in the root zone to above the critical level $(1.5 \%$ to $2.0 \%$ SOC or $3 \%$ to $4 \%$ soil organic matter content) is essential to enhancing soil health (Lal 2016b). Soil health refers to the capacity of soil to function as a vital living system to sustain biological productivity; maintain environmental quality; and promote plant, animal and human health (Doran et al. 2002). Soils of agroecosystems must be restored through a soil-centric paradigm shift and by not taking soils for granted. Concentration of SOC in the root zone is the most reliable indicator of the extent and severity of degradation/erosion (Rajan et al. 2010), just as soil health is an indicator of sustainable management (Doran et al. 2002), and of human and animal health (Oliver 1997). A healthy soil can also suppress pathogens and diseases (Larkin and VanAlfen 2015; Janvier et al. 2007) and reduce the dependence on pesticides. Soil health is an integrative property, an indicator of soil's capacity to respond to innovations (e.g., improved varieties, irrigation, fertilizers, etc.), and a criterion in its ability to deliver essential ecosystem services for human wellbeing and nature conservancy.

Soil health can be assessed and managed by quantifying the flow of energy and $\mathrm{C}$ between functions, which is an essential but challenging task (Kibblewhite et al. 2008). Thus, an integrative soil health test is used to evaluate the impact of soil management (Idowu et al. 2017). Flow of energy and $\mathrm{C}$ among functions is intricately interconnected with SOC and its turnover (Lal 2016b).
Adoption of site-specific BMPs is essential to improving SOC and restoring soil health. While there is no one-size-fits-all technology that can be used on 300,000 known soil services worldwide, the basic principle of enhancing SOC concentration is to create a positive soil C budget - input of biomass $\mathrm{C}$ into the soil must exceed the losses of $\mathrm{C}$ by erosion, mineralization, and leaching. A system-based conservation agriculture (i.e., with four components: mulch and residue retention, cover cropping and complex rotations, integrated nutrient management, and no-till) can minimize erosion and enhance SOC concentration and stock (Lal 2015; Amado et al. 1998; Ashworth et al. 2014). The mean residence time of SOC sequestered can be prolonged in soils (deep solum, high clay + fine silt content, 2:1 type expanding clays with high water holding capacity), which enhance formation of organo-mineral complexes (Newcomb et al. 2017). The strategy is to judiciously manage the coupled cycles of water, SOC, and $\mathrm{N}$ by reducing losses of water, managing emission of GHGs, and restoring soil structure and biotic processes (figure 2).

\section{SPATIAL CONTRACTION OF AGROECOSYSTEMS}

In Sub-Sahara African (SSA) soils, which bypassed the Green Revolution of 1960s, there is a justifiable need of expanding the land area equipped for irrigation and also increasing the rate of fertilizer input on cropland. On global basis, however, there is an excessive use and gross misuse of

\section{Figure 2}

Managing coupled cycling of water, soil organic carbon, and nitrogen.

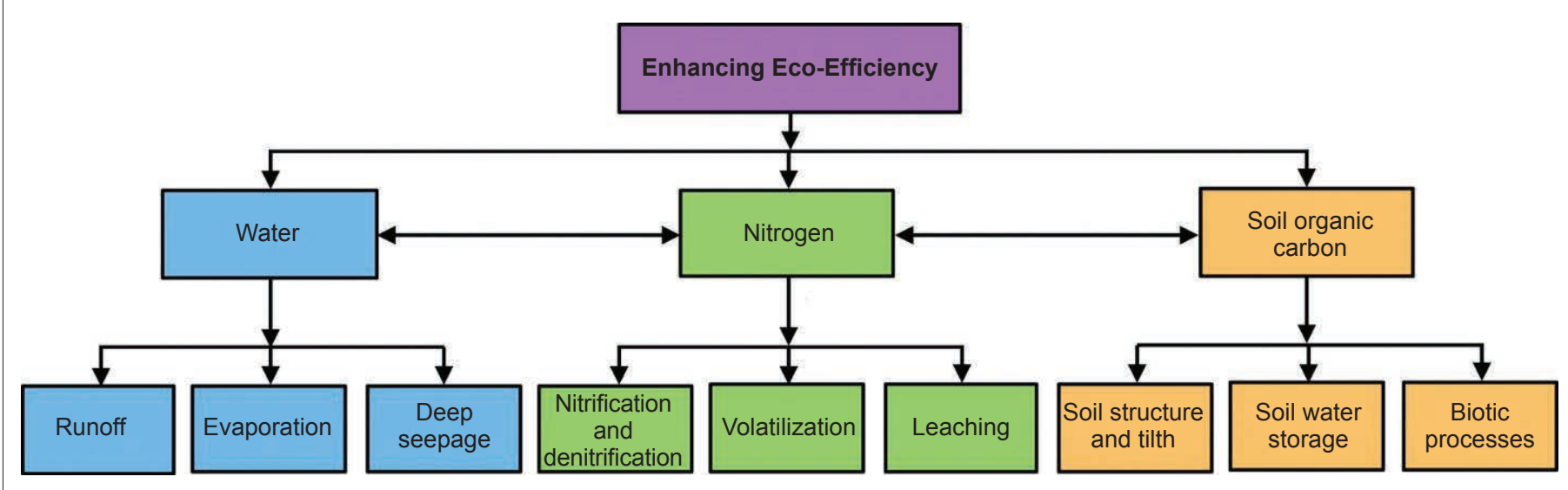


agricultural land area, irrigation water, fertilizers, pesticides, and other energy-based inputs. Expanding land area and using more inputs is a misguided, no-brainer option and an easy temptation that must be resisted. Indeed, there are better and more environmentally friendly options of advancing the Sustainable Development Goals or the Agenda 2030 of the United Nations.

The world produces enough food already to feed a population of 10 billion. However, food and nutritional security must be achieved by (1) reducing the food waste estimated at $30 \%$ to $40 \%$ of grains produced globally; (2) increasing access to food by addressing poverty, inequality, political instability, and civil unrest; (3) improving distribution; (4) increasing use of pulses and plant-based diet (Lal 2017b); and (5) increasing agronomic productivity from existing lands by narrowing the yield gap through restoration of degraded soils and recarbonization of soil and the biosphere.

Narrowing the yield gap-especially in developing countries of SSA and South Asia (SA) along with those in Central America and the Caribbean-necessitates restoring degraded soils; enhancing biological $\mathrm{N}$ fixation by legumes and nonlegumes (Ferreri et al. 2018); adapting site-specific BMPs for water conservation in the root zone; delivering water and nutrients directly to plant roots at the critical growth stages; and growing improved cultivars and species. Among desirable attributes of production systems that will lead to spatial contraction of agricultural land area are productivity, stability, equitability, autonomy or self-sufficiency, sustainability, and the eco-efficiency. The term "ecoefficiency" implies producing more from less, and the term "sustainability" must be multidimensional: environmental, economic, social, and institutional.

Similar to croplands, even modest improvements in livestock systems can significantly reduce further land expansion for feed production, especially by adapting integrated systems, which improve the efficiency of the entire food system. The presently used land area of $2.506 \times 10^{9}$ ha $\left(6.192 \times 10^{9} \mathrm{ac}\right)$ for raising livestock can be reduced to $2 \times 10^{9}$ ha $\left(4.942 \times 10^{9}\right.$ ac) by improving efficiency. The land area used for cereal production to feed live- stock $\left(2.10 \times 10^{8}\right.$ ha $\left.\left[5.19 \times 10^{8} \mathrm{ac}\right]\right)$ can also be saved by grass-fed systems. Animals can be raised on lands not used for crop production and by conversion of coproducts into protein-rich food (Herrero et al. 2013; Mottet et al. 2017). Nutrient management, especially $\mathrm{N}$ and $\mathrm{P}$, is the key issue. For example, N, $\mathrm{P}$, and $\mathrm{K}$ harvested in corn (Zea mays L.) is 36, 8, and $9 \mathrm{~kg}$ $\mathrm{Mg}^{-1}$ (72, 16, and $18 \mathrm{lb} \mathrm{tn}^{-1}$ ) for grains compared with 15,2 , and $37 \mathrm{~kg} \mathrm{Mg}^{-1}$ for stover (Bundy 1998). Therefore, stover/ straw must be recycled and part of the $\mathrm{N}$ demand met through biological $\mathrm{N}$ fixation by legume-based rotations (Lal 2017b). Indeed, the current (circa 2000) levels of cereal production can be achieved with $50 \%$ less $\mathrm{N}$ application, and production with the current level of input could be increased $60 \%$ by an efficient spatial pattern of $\mathrm{N}$ use (i.e., more in SSA and less in China) (Mueller et al. 2014). The key strategy is of achieving synchrony between $\mathrm{N}$ supply and crop demand without excess deficiency (Cassman et al. 2002).

\section{Table 2}

Hypothetical scenarios of the land area, irrigation water, and global fertilizer use for production during the twenty-first century (Adapted from Lal 2016a, 2017a; Mottet et al. 2017). Numbers in parentheses reflect the present situation.

\begin{tabular}{|c|c|c|c|c|}
\hline \multirow[b]{2}{*}{ Land area } & \multicolumn{4}{|l|}{ Year } \\
\hline & 2005 to 2007 & 2050 & 2080 & 2100 \\
\hline \multicolumn{5}{|l|}{ Cereal production } \\
\hline Production (10 $\left.10^{6}\right)$ & 2,012 & 3,012 & 3,350 & 3,540 \\
\hline The desired yield $\left(\mathrm{kg} \mathrm{ha}^{-1}\right)$ & 3,280 & 5,000 & 6,000 & 7,000 \\
\hline Required land area (Mha) & 613 & 600 & 560 & 500 \\
\hline \multicolumn{5}{|l|}{ Pulses and food legumes } \\
\hline Production (106 Mg) & (70) & 443 & 485 & 511 \\
\hline The desired yield $\left(\mathrm{kg} \mathrm{ha}^{-1}\right)$ & $(700)$ & 1,800 & 2,010 & 2,150 \\
\hline Required land area (Mha) & $(85.6)$ & 245 & 240 & 238 \\
\hline \multicolumn{5}{|l|}{ Livestock } \\
\hline Forage production (109 Mg) & (6) & 7.2 & 8.1 & 9.0 \\
\hline The desired forage yield $\left(\mathrm{kg} \mathrm{ha}^{-1}\right)$ & 2,400 & 3,230 & 4,130 & 4,950 \\
\hline Required land area (Mha) & $(2,506)^{*}$ & 2,230 & 1,985 & $1,820 \dagger$ \\
\hline Global fertilizer need $\left(10^{6} \mathrm{Mg}\right)$ & (200)‡ & 160 & 120 & 100 \\
\hline \multicolumn{5}{|l|}{ Irrigated land area } \\
\hline Conversion to DSI and fertigation (Mha) & $(325)$ & 365 & 400 & 425 \\
\hline Volume of water use $\left(\mathrm{km}^{3} \mathrm{y}^{-1}\right)$ & $(3,986)$ & 3,200 & 2,480 & 2,000 \\
\hline
\end{tabular}

*The reported area of permanent grassland in 3,500 Mha (FAOSTAT 2017) of which 1,500 Mha is marginal lands.

† Mottet et al. (2017) estimated that 685 Mha of grassland currently used will be converted to other uses. ¥Present fertilizer use is $200 \times 10^{6} \mathrm{Mg} \mathrm{y}^{-1}$ (FAOSTAT 2017) and it can be reduced by $50 \%$ and redistributed spatially. 
There is a need to reduce fertilizer use by improving the use efficiency, reducing losses by erosion along with leaching and volatilization, and improving the spatial distribution. The objective is to reduce fertilizer use from $200 \times 10^{6} \mathrm{Mg} \mathrm{y}^{-1}(220$ $\left.\times 10^{6} \mathrm{tn}^{\mathrm{yr}^{-1}}\right)$ at present to $100 \times 10^{6} \mathrm{Mg}$

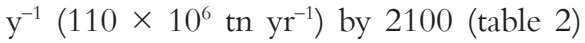
but improve the spatial distribution and reduce losses. In 2016, the rate of fertilizer use $\left(\mathrm{kg} \mathrm{ha}^{-1}\right.$ of arable land) was 138 (123 $\left.\mathrm{lb} \mathrm{ac}^{-1}\right)$ for the world, $565\left(504 \mathrm{lb} \mathrm{ac}^{-1}\right)$ for China, 218 (194 lb ac$\left.{ }^{-1}\right)$ for Germany, 175 $\left(156 \mathrm{lb} \mathrm{ac}^{-1}\right)$ for Brazil, $165\left(147 \mathrm{lb} \mathrm{ac}^{-1}\right)$ for India, $158\left(141 \mathrm{lb} \mathrm{ac}^{-1}\right)$ for South America, and only $16\left(14 \mathrm{lb} \mathrm{ac}^{-1}\right)$ for SSA. If the average rate of fertilizer for arable land can be increased to $150 \mathrm{~kg} \mathrm{ha}^{-1}\left(134 \mathrm{lb} \mathrm{ac}^{-1}\right)$ by 2100 , the total fertilizer demand for 5 $\times 10^{8} \mathrm{ha}\left(12 \times 10^{8} \mathrm{ac}\right)$ of land area under cereals will be only $75 \times 10^{6} \mathrm{Mg}(8.27$ $\left.\times 10^{7} \mathrm{tn}\right)$. Thus, $100 \times 10^{6} \mathrm{Mg} \mathrm{y}^{-1}(110$

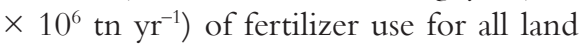
uses (table 2) is a feasible estimate. Similar to contracting the land area and the input of chemicals and water, enhancement of eco-efficiency by adopton of proven and known site-specific technologies can save land and water, improve the environment, and meet the needs of the growing and progressively affluent population of India (table 3).

There is a strong coupling of the biogeochemical and biogeophysical cycles of water, C, N,P, and sulfur (S) (Lal 2010).Thus, eco-efficiency can be greatly enhanced by judicious management of SOC and soil water. An optimal range of SOC in the root zone is $2 \%$ (Loveland and Webb 2003). Restoring SOC, to recarbonize the historic depletion of $\sim 130 \mathrm{Pg}\left(1.43 \times 10^{11} \mathrm{tn}\right) \mathrm{C}$ from world soils (Lal 2018), has numerous cobenefits. In addition to creating a drawdown of atmospheric $\mathrm{CO}_{2}$ by $\sim 60 \mathrm{ppm}$, it would enhance soil health, plant available water resources, and the use efficiency of fertilizers and other energy-based inputs. Conventional tillage, including plowing and disking, decreases the abundance and the biomass of earthworms (Jesus et al. 2017), but nature's plow must be fed by retention of crop residues. Soil biota is the bioengine of the earth, and it must be enhanced by regular and appropriate input of biomass, the food source and habitat of soil biota. A

\section{Table 3}

A scenario of future land area and inputs for agriculture using soil-centric technology in India.

\begin{tabular}{|c|c|c|c|c|}
\hline Parameter & 2017 & 2030 & 2050 & 2100 \\
\hline Population $\left(10^{6}\right)$ & 1,339 & 1,513 & 1,659 & 1,517 \\
\hline Per capita arable land (ha) & 0.12 & 0.08 & 0.07 & 0.065 \\
\hline Cropland area (Mha) & 130 & 120 & 115 & 100 \\
\hline Grain production & 273 & 320 & 370 & 400 \\
\hline Soil degradation (Mha) & 130 & 100 & 50 & 20 \\
\hline Irrigated land area (Mha $\left.\left[\mathrm{km}^{3}\right]\right)$ & $70(200)$ & $75(150)$ & $82(100)$ & $100(75)$ \\
\hline Fertilizer use $\left(10^{6} \mathrm{Mg}\right)$ & 30 & 25 & 20 & 15 \\
\hline In-field residue burning ( $\left.10^{6} \mathrm{Mg}\right)$ & 100 & 0 & 0 & 0 \\
\hline Pesticide use $\left(10^{3} \mathrm{Mg}\right)$ & 56 & 30 & 20 & 10 \\
\hline Cereal Yield (Mg ha $\left.{ }^{-1}\right)$ & 2.1 & 2.7 & 2.8 & 4.0 \\
\hline Post-harvest losses (\%) & 34 & 10 & 5 & 5 \\
\hline Organic manure $\left(10^{6} \mathrm{Mg}^{-1}\right)$ & 200 & 300 & 400 & 500 \\
\hline
\end{tabular}

widespread adoption of innovative technologies for ensuring environmental services will necessitate explicit policy interventions (Rudel et al. 2009).

\section{CONCLUSIONS}

The Green Revolution of the 1960s enhanced food production and spared the land. However, excessive use of irrigation and indiscriminate use of fertilizers and pesticides had strong adverse impacts on the environment, including depletion of SOC stock, increased risks of soil degradation by erosion and salinization, depletion and contamination of aquifers, loss of biodiversity, and emission of GHGs into the atmosphere. The number of food-insecure people may increase because of the unprecedented increase in world population, rapid economic growth, and change in diet preferences toward animal-based diets. Furthermore, the per capita cropland area is also decreasing because of growth in population, degradation of soil, urbanization, and other competing uses. Thus, the strategy is to reconcile the demand for food production with the need for restoration of soil and reduction in the environmental footprint of agroecosystems. This can be achieved by conversion to restorative land uses and adoption of proven BMPs of managing soil, water, vegetation, and livestock. The strategy is to improve soil health by restoring SOC stock, enhance the use efficiency of inputs, narrow the yield gap, and implement systems of sus- tainable intensification of agroecosytems. The goal is to produce more from lessless land area, less water use, less input of fertilizers and pesticides, and less energy use. The much-needed paradigm shift will also need identification and implementation of appropriate policies to translate scientific knowledge into action.

\section{REFERENCES}

Alexandratos, N., and J. Bruinsma. 2012. World Agriculture Towards 2030/2050: The 2012 Revision. ESA Working Paper \#12-03. Rome: Food and Agriculture Organization of the United Nations.

Amado, T.J.C., S.B. Fernandez, and J. Michicruk. 1998. Nitrogen availability as affected by ten year of cover crop and tillage system in southern Brazil. Journal of Soil and Water Conservation 53(3):268-271.

Arneth, A., S. Sitch, J. Pongratz, B.D. Stocker, P. Ciais, B. Poulter, A.D. Bayer, A. Bondeau, L. Calle, L.P. Chini, T. Gasser, M. Fader, P. Friedlingstein, E. Kato, W. Li, M. Lindeskog, J.E.M.S. Nabel, T.A.A. Pugh, E. Robertson, N. Viovy, C. Yue, and S. Zaehle. 2017. Historical carbon dioxide emissions caused by land-use changes are possibly larger than assumed. Nature Geoscience 10:79-86.

Ashworth, A.J., F.L. Allen, A.M. Saxton, and D.D. Tyler. 2014. Soil organic carbon sequestration rates under crop sequeene diversity, biocovers under no-tillage. Soil Science Society of America Journal 78:1726-1733.

Ausbel, J.H., I.K. Wenick, and P.A. Waggoner. 2013. Peak farmland and the prospect for land sparing. Population and Development Review 38(S1):221-242. 
Bai, Z.G., D.L. Dent, L. Olsson, and M.E. Schaepman. 2008. Proxy global assessment of land degradation. Soil Use Management 24:223-234.

Battye, W., V.P. Aneja and W.H. Schlesinger. 2017. Is nitrogen the next carbon? Earth's Future 5:894-904.

Bruinsma, J. 2009. The resource outlook to 2050: By how much do land, water use and crop yields need to increase by 2050? Expert Meeting on How to Feed the World in 2050. Rome: Food and Agriculture Organization of the United Nations Economic and Social Development Department.

Bundy, L.G. 1998. Corn Fertilization. Madison, WI: Cooperative Extension Publishing, University of Wisconsin.

Canfield, D., A. Glazer, and P. Falkowski. 2010. The evolution and future of earth's nitrogen cycle. Science 330:192-196.

Cassman, K., A. Dobermann, and D. Walters. 2002. Agroecosystems, nitrogen-use efficiency, and nitrogen management. Ambio 31:132-140.

Crowther, T.W., K.E.O. Todd-Brown, C.W. Rowe, W.R. Wieder, J.C. Carey, M.B. Machmuller, B.L. Snoek, S. Fang, G. Zhou, S.D. Allison, J.M. Blair, S.D. Bridgham, A.J. Burton,Y. Carrillo, P.B. Reich, J.S. Clark, A.T. Classen, F.A. Dijkstra, B. Elberling, B.A. Emmett, M. Estiarte, S.D. Frey, J. Guo, J. Harte, L. Jiang, B.R. Johnson, G. Kröel-Dulay, K.S. Larsen, H. Laudon, J.M. Lavallee, Y. Luo, M. Lupascu, L.N. Ma, S. Marhan, A. Michelsen, J. Mohan, S. Niu, E. Pendall, J. Peñuelas, L. PfeiferMeister, C. Poll, S. Reinsch, L.L. Reynolds, I.K. Schmidt, S. Sistla, N.W. Sokol, P.H. Templer, K.K. Treseder, J.M. Welker, and M.A. Bradford. 2016. Quantifying global soil carbon losses in response to warming. Nature 540:104-108.

Doran, J., S. Stamatiadis, and J. Haberern. 2002. Preface: Soil health as an indicator of sustainable management. Agriculture, Ecosystems, and Environment 88:107-110.

FAO (Food and Agriculture Organization of the United Nations). 2009. How to Feed the World in 2050. Rome: Food and Agriculture Organization of the United Nations.

FAO. 2015. Regional Overview of Food Insecurity, Asia and the Pacific. Bangkok: Food and Agriculture Organization of the United Nations.

FAOSTAT. 2017. FAOSTAT Statistics Database. Rome: Food and Agricultural Organization of the United Nations.

Fowler, D., M. Coyle, U. Skiba, M.A.Sutton, J.N.Cape, S. Reis, L.J. Sheppard, A. Jenkins, B. Grizzetti, J.N Galloway, P.Vitousek, A. Leach, A.F. Bouwman, K. Butterbach-Bahl, F. Dentener, D. Stevenson, M. Amann, and M. Voss. 2013. The global nitrogen cycle in 21st Century. Philosophical Transactions of the Royal Society B 368:1-12.

Ferreri, R.A., E. Herman, B. Babst, and M.J. Schueller 2018. Managing the soil nitrogen cycle in agroecosystems. In Advances in Soil Science-Soil Nitrogen, eds. R. Lal and B.A. Stewart, 343-360. Boca Raton: CRC Press.

Frank, E.G., and W. Schlenker. 2016. Balancing economic and ecological goals: What are the trade-offs between economic development and ecosystem conservation? Science 353:651-652.

Gibbs, H., and J. Salmon. 2015. Mapping the world's degraded lands. Applied Geography 57:12-21

Herrero, M., P. Havlík, H. Valin, A. Notenbaert, M.C. Rufino, P.K. Thornton, M. Blümmel, F Weiss, D. Grace, and M. Obersteiner. 2013. Biomass use, production, feed efficiencies, and greenhouse gas emissions from global livestock systems. Proceedings of the National Academy of Sciences of the United States of America 110:20888-20893.

Herridge, D., M. Peoples, and R. Boddey. 2008. Global inputs of biological nitrogen fixation in agricultural systems. Plant and Soil 311:1-18.

Idowu, O., H.M. van Es, G.S. Abawi, D.W. Wolfe, R.R. Schindelbeck, B.N. Moebius-Clune, and B.K. Gugino. 2009. Use of an integrative soil health test for evaluation of soil management impacts. Renewable Agriculture and Food Systems 24:214-224,

Janvier, C., F. Villeneuve, C. Alabouvette, V. EdelHermann, T. Matelille, and C. Steinberg. 2007. Soil health through soil disease suppression: Which strategy from descriptors to indicators? Soil Biology and Biochemistry 39:1-23

Jesus, M., I. Briones, and O. Schmidt. 2017. Conventional tillage decreases the abundance and biomass of earthworms and alters their community structure in a global meta-analysis. Global Change Biology 23:4396-4419

Kibblewhite, M., K. Ritz, and M. Swift. 2008. Soil health in agricultural systems. Philosophical Transactions of the Royal Society B-Biological Sciences 363:685-701.

Lal, R. 2010. Managing soils and ecosystems for mitigating anthropogenic carbon emission and advancing global food security. BioScience 60(9):708-721.

Lal, R. 2015. A system approach to conservation agriculture. Journal of Soil and Water Conservation 70(4):82A-88A, doi:10.2489/jswc.70.4.82A.

Lal, R. 2016a. Feeding 11 billion on 0.5 billion hectare of cropland. Food and Energy Security Journal 5(4):239-251.

Lal, R. 2016b. Soil health and carbon management. Food and Energy Security Journal 5(4):212-222.
Lal, R. 2017a. Managing the necessary evil. In Advances in Soil Science-Soil Nitrogen, eds. R. Lal and B.A. Stewart. Boca Raton: CRC Press.

Lal, R. 2017b. Improving soil health and human protein nutrition by pulses-based cropping systems. Advances in Agronomy 145:167-204.

Lal, R. 2018. Digging deeper: A holistic perspective of factors affecting soil organic carbon sequestration in agroecosystems. Global Change Biology. https://doi.org/10.1111/gcb.14054.

Lambin, E.F., and P. Meyfroidt. 2011. Global land use change, economic globalization and the looming land scarcity. Proceedings of the National Academy of Sciences of the United States of America 108:3465-3472.

Larkin, R., and N. VanAlfen. 2015. Soil health paradigms and implications for disease management. Annual Review of Phytopathology 53:199-221

Loveland, P., and J. Webb. 2003. Is there a critical level of organic matter in the agricultural soils of temperate regions: A review. Soil and Tillage Research 70:1-18

Luke, C.M., and P.M. Cox. 2011. Soil carbon and climate change: From the Jenkinson effect to the compost-bomb instability. European Journal of Soil Science 62:5-12

Mottet, A., C. de Haan, A. Falcucci, G. Tempio, C. Opio, and P. Gerber. 2017. Livestock: On our plats or eating at our table? A new analysis of the feed/food debate. Global Food Security 14:1-8.

Mueller, N., P.C. West, J.S. Gerber, G.K. MacDonald, S. Polasky, and J.A. Foley. 2014. A tradeoff frontier for global nitrogen use and cereal production. Environmental Research Letters 9, doi:10.1088/1748-9326/9/5/054002.

Newbold, T., L.N. Hudson, S.L.L. Hill, S. Contu, I. Lysenko, R.A. Senior, L. Börger, D.J. Bennett, A. Choimes, B. Collen, J. Day, A. De Palma, S. Díaz, S. Echeverria-Londoño, M.J. Edgar, A. Feldman, M. Garon, M.L.K. Harrison, T. Alhusseini, D.J. Ingram,Y. Itescu, J. Kattge,V. Kemp, L. Kirkpatrick, M. Kleyer, D.L.P. Correia, C.D. Martin, S. Meiri, M. Novosolov, Y. Pan, H.R.P. Phillips, D.W. Purves, A. Robinson, J. Simpson, S.L. Tuck, E. Weiher, H.J. White, R.M. Ewers, G.M. Mace, J.P.W. Scharlemann, and A. Purvis. 2015. Global effects of land use on local terrestrial biodiversity. Nature 520:45-50.

Newcomb, C., N. Qafoku, J. Grate, V. Bailey, and J. De Yoreo. 2017. Developing a molecular picture of soil organic matter-mineral interactions by quantifying organo-mineral binding. Nature Communications 8:396.

Nobre, C., G. Sampaio, L.S. Borma, J.C. CastillaRubio, J.S. Silva, and M. Cardoso. 2016. Land-use and climate change risks in the Amazon and 
the need of a novel sustainable development paradigm. Proceedings of the National Academy of Sciences of the United States of America 11:10759-10768.

Oliver, M. 1997. Soil and human health: A review. European Journal of Soil Science 48:573-592.

Phalan, B., R.E. Green, L.V. Dicks, G. Dotta, C. Feniuk,A.Lamb, B.B.N. Strassburg, D.R.Williams, E.K.H.J. zu Ermgassen, and A, Balmford. 2016. How can higher-yield farming help to spare nature? Science 351:450-451.

Rajan, K., A. Natarajan, K. Kumar, M. Badrinath, and R. Gowda. 2010. Soil organic carbon: The most reliable indicator for monitoring land degradation by soil erosion. Current Science 99:823-827.

Reick, C., T. Raddatz, J. Pongratz, and M. Claussen. 2010. Contribution of anthropogenic land cover change emissions to pre-industrial atmospheric $\mathrm{CO}_{2}$. Tellus Series B-Chemical and Physical Meteorology 62:329-336.

Roser, M., and H. Ritchie. 2017. Yields and land use in agriculture. https://ourworldindata.org/ yields-and-land-use-in-agriculture/.

Ruddiman, W., and E. Ellis. 2009. Effect of per-capita land use changes on Holocene forest clearance and $\mathrm{CO}_{2}$ emissions. Quaternary Science Reviews 28:3011-3015.

Ruddiman, W. 2003. The anthropogenic greenhouse era began thousands of years ago. Climatic Change 61:261-293

Rudel, T.K., L. Schneider, M. Uriarte, B.L. Turner II, R. DeFries, D. Lawrence, J. Geoghegan, S. Hecht, A. Ickowitz, E.F. Lambin, T. Birkenholtz, S. Baptista, and R. Grau. 2009. Agricultural intensification and changes in cultivated areas, 1970-2005. Proceedings of the National Academy of Sciences of the United States of America 106(49):20675-20680.

Sanderman, J., T. Hengl, and G. Fiske. 2017. Soil carbon debt of 12,000 years of human land use. Proceedings of the National Academy of Sciences of the United States of America 114:9575-9580.

Tie, X., R. Zhang, G. Brasseur, and W. Lei. 2002. Global NOx production by lightning. Journal of Atmospheric Chemistry 43:61-74.

United Nations. 2014. Open Working Group Proposal for Sustainable Development Goals. New York: United Nations Department of Economic and Social Affairs. https://sustainabledevelopment.un.org/focussdgs.html

Vitousek, P., D. Menge, S. Reed, and C. Cleveland. 2013. Biological nitrogen fixation: Rates, patterns and ecological controls in terrestrial ecosystems. Philosophical Transactions of the Royal Society B-Biological Sciences 368:20130119. 